\title{
Socio-Environmental Impact of River Sand Mining: An Example from Neyyar River, Thiruvananthapuram District of Kerala, India
}

\author{
Shaji $\mathrm{J}^{1}$, Dr R Anilkuar ${ }^{2}$ \\ ${ }^{I}$ (Resources Analysis Division, Centre for Earth Science Studies, Trivandrum, Kerala, India) \\ ${ }^{2}$ (Dept. Of Geography, University College, Trivandrum, Kerala, India)
}

\begin{abstract}
Indiscriminate sand mining can lead to the degradation of riverine environment. The study conducted in the Neyyar river basin shows that indiscriminate and illegal sand mining has created many problems in the environmental setting and water quality of the river basin. In the basinal area, it has created certain negative impacts on landuse, landscape and land stability. Apart from these impacts on physical environment of the river basin, it has also contributed many adverse impacts on the socio-economic well being of the area.
\end{abstract}

Keywords - Environmental impacts, Neyyar River, River Sand mining, society.

\section{Introduction}

Rivers are the most important life supporting system of nature. For centuries, humans have been enjoying the natural benefits provided by rivers without understanding much on how the river ecosystem functions and maintains its vitality (Naiman 1992; Naiman and Bilby 1998). Man has changed the nature of many of the world's rivers by controlling their floods, constructing large impoundments (Ittekkot and Lanne 1991), over exploitation of living and non living resources (Macfarlane and Mitchell 2003;Kitetu and Rowan 1997) and using rivers for disposal of wastes (Haslam,1990).Among these, indiscriminate extraction of nonliving resources like sand and gravel from riverbed is the most disastrous as this activity threatens the very existence of the river ecosystem. A review of literature reveals that indiscriminate extraction of river sand and gravel many folds higher than natural replenishments can impart serious offsite and onsite impacts. This ultimately leads to changes in channel form, lowering of water table, landscape instability, land degradation etc. As these adverse effects become increasingly recognized and understood, in stream and river bank sand mining have been subjected to increasing scientific scrutiny. Although more focused researches leading to restoration of river environments are progressing in many developed countries, much attention has not been given to the rest of the world.

The present investigation is attempted at analysing the socio - environmental effects of river sand mining in the Neyyar River of Thiruvananthapuram district, Kerala state. Neyyar River has been subjected to indiscriminate sand extraction over the past 4-5 decades consequent to economic development and rise in liberalized housing schemes from the banking sector for building constructions since early 1970's. Lack of sufficient information regarding the negative effects of sand mining is a major setback for laying strategies for the conservation and management of the catchment area of the river. Considering the importance of assessments on the extent of environmental degradation due to indiscriminate sand mining, an attempt has been made in this paper to address a few aspects about the impacts of sand mining on the environments of rivers in the southwestern coast of Kerala, taking the Neyyar river basin as an example.

\section{Study Area}

The Neyyar River is the southern-most river of Kerala State (Fig. 1). It emerges from Agastya hills at about $1865 \mathrm{~m}$ above MSL and debouches into Arabian Sea after flowing a distance of $56 \mathrm{Km}$. The Neyyar River basin lies between $8^{\circ} 15^{\prime}$ to $8^{\circ} 40^{\prime} \mathrm{N}$ latitudes and $77^{\circ} 00^{\prime}$ to $77^{\circ} 20^{\prime} \mathrm{E}$ longitude in Thiruvananthapuram District. The basin has a total area of $483 \mathrm{sq}$. $\mathrm{km}$ covering 24 panchayats. The main tributaries of the Neyyar are Chit Ar, Kall Ar, Karavali Ar, Mull Ar, Aruvikod Thodu, Maruthurthodu, Edamalaithodu and Talakke Thodu. 
It receives an average annual rainfall of $1542 \mathrm{~mm}$. Physiographically, the study area can be divided into midlands $(8-75 \mathrm{~m})$ and lowlands(less than $8 \mathrm{~m}$ ). The Neyyar river basin mainly comprises of three different lithological units, i.e. Archaean Formation in the Upper region, the Archaean Formation except quartzite of khondalite group in the Middle region and coastal sand and alluvium, sandstone and clay with lignite intercalation of Warkalli (Varkala) formation and quartz feldspar hypersthenes granulites, charnockitic gneiss and hypersthenes diopside gneiss of charnockite group in the Lower region. The area experiences tropical humid climate with an average annual rainfall of about $3300 \mathrm{~mm}$. The temperature varies from $20^{0} \mathrm{C}$ to $39^{0} \mathrm{C}$. Humidity is high (more than $80 \%$ ) during the monsoon period.

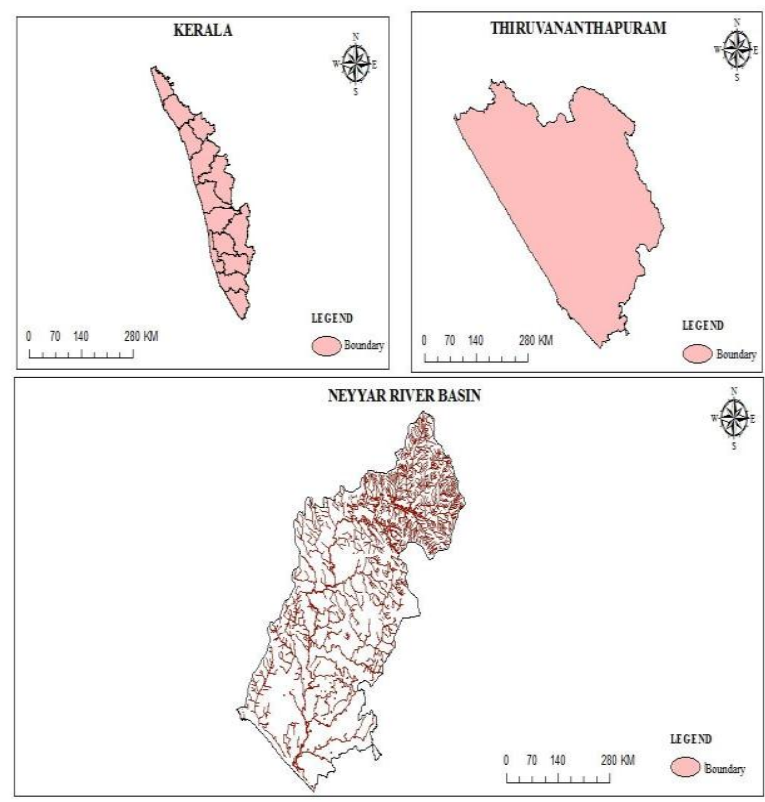

Fig. 1 Study Area

\section{Methodology}

The locations of sand mining sites were delineated on the base map prepared from the Survey of India Topographical maps on a scale 1:50,000 using the coordinates of latitude and longitude collected through Explorist 600 Mac Millan GPS Receiver. An intensive field survey has been conducted in 3 selected sites using semi-structured interviews, PRA and field mapping techniques. The widening of river bank due to sand mining is analysed by comparing the area represented in the SOI Top sheets (1969) and Google Earth Imagery (2008) with the field maps prepared.

\section{Sand Mining in the Neyyar River Basin}

River sand is mined extensively from the lower course of the Neyyar River, stretching for about $30 \mathrm{KM}$ from Aruvippuram in the north to Poovar in the south. All the sand mining locations of the basin are within this 30 KM stretch. Aruvippuram, Chemparathivila, Palakkadavu, Arakkunnu, Olathani and Poovar are the major sand mining sites in the Neyyar River basin. Among these, Olathani, Arakkunnu and Palakkadavu are the sand mining sites selected for the present investigation. The sand mining locations are locally known as 'Kadavus' and the selected locations, Olathani, Arakkunnu and Palakkadavu have length of .of $2.2 \mathrm{Km}, 2.9 \mathrm{Km}$ and 1.6 $\mathrm{Km}$ respectively. In stream, sand mining as well as flood plain mining is most prevalent in these areas (Fig.2).

It was reported during the investigation that river sand accumulation was a problem in these three selected sites before 30 years, as it caused frequent floods in the basinal area and the flood that occurred in 1978 is an example which made a severe damage in the catchments. The sand extraction from the riverbed in the earlier periods was done with traditional methods without harming the environment, under the supervision of local authorities. The sand thus extracted was used locally for construction purposes. This situation has changed since 1990 when commercial sand extraction started in the area by invading the river banks of the Neyyar River even by encroaching upon the land bordering the river banks. There are instances when the sand mafia even purchased the private lands to extract the sand by digging the lands adjacent to the river bank. Whenever the land is used for the extraction of sand, the river water enters into that part and makes the area a part of the river which further compels the neighbouring people to sell their land holdings for sand extraction either due to the encroachment of river or threats from sand mafia. 


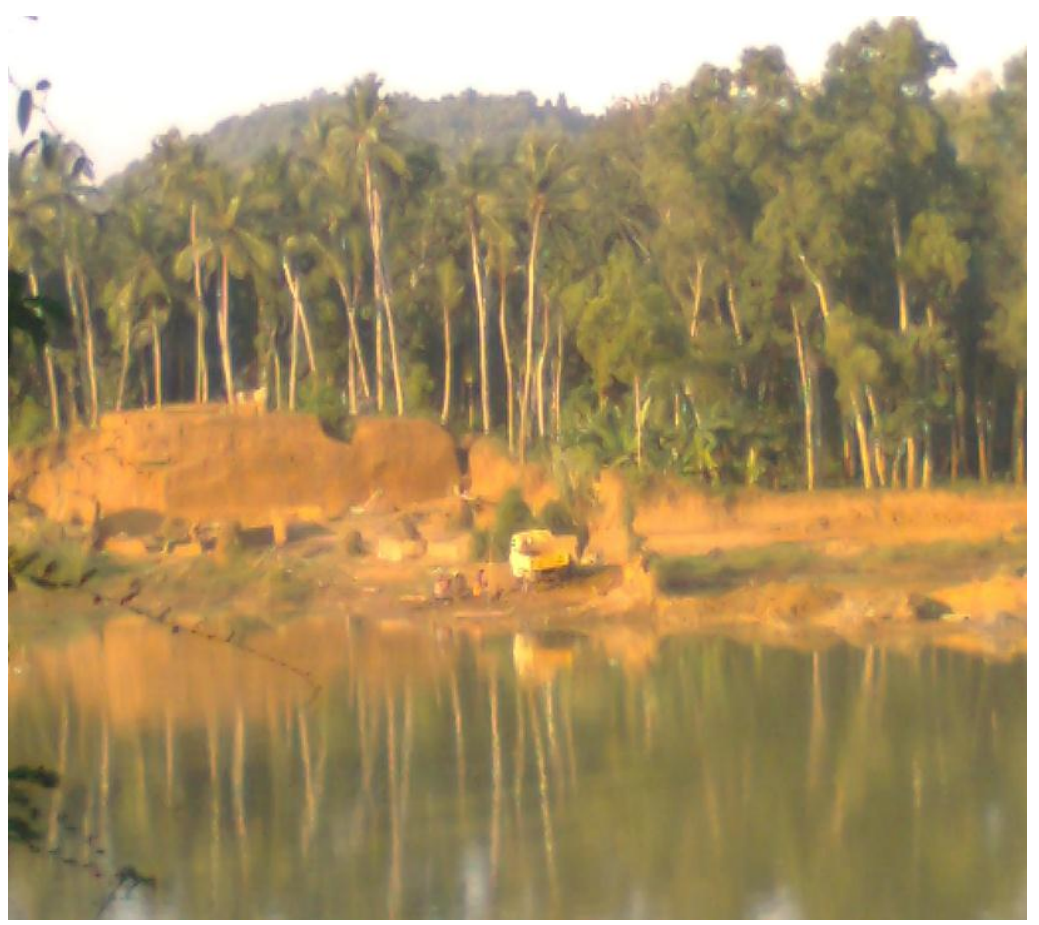

Fig.2 Flood plain sand mining in Arakkunnu

The total number of workers (Table.1) engaged in the sand mining activities in these three sites is 775 . It was reported that these numbers were very less in the earlier periods when sand was not commercially exploited in this rural area which existed on agrarian economy. The sand mining activities start in the early morning and prolongs till the noon. As the people can earn much within a short time, this activity attracts more young people in these areas to this illegal mining. The workers include sand miners, head load workers and transporting persons which form the diverse activities that attract people from various sectors to this field. The age structures of the people engaged in these activities vary between 17 years and 55years. The wages offered to the labours is attractive and is one of the main reasons why more number of people move towards sand mining related activities.

Table 1

\begin{tabular}{|l|l|l|l|l|l|}
\hline Sl.No & Sand Mining Site & $\begin{array}{l}\text { Mining } \\
\text { started } \\
\text { since }\end{array}$ & $\begin{array}{l}\text { No. of workers } \\
\text { at present }\end{array}$ & $\begin{array}{l}\text { No. of } \\
\text { vessels used }\end{array}$ & $\begin{array}{l}\text { Quantity/load } \\
\text { per day }\end{array}$ \\
\hline 1 & Arakkunnu & 2000 & 500 & 75 & 50 \\
\hline 2 & Palakkadavu & 1990 & 75 & 10 & 8 \\
\hline 3 & Olathani & 1980 & 200 & 50 & 25 \\
\hline
\end{tabular}

Sand Mining in the Selected Sites of Neyyar River Basin

It was also found during the investigation that there is a noticeable increase in the number of vessels used in sand mining activity in the area, which numbers 105 in all these three sites at present. The sand extraction in the mining sites are of the order Arakkunnu> Olathani > Palakkadavu (Table 1). The quantity of sand extracted per day in the selected sites varies from 8 lorry loads in Palakkadavu to 50 lorry loads in Arakkunnu.

\section{Environmental Impact of Sand Mining in the Neyyar River Basin}

River basins have long been exploited as source of fine aggregates for building constructions. Depending up on the geomorphic/ geologic setting, river sand mining can impose serious environmental consequences in the long run.The cumulative effects of uncontrolled sand mining have substantially altered the physical as well as social environment of Neyyar river basin. It is noticed during the investigation that degradation of river is severe in the alluvial reaches of midland compared to the low lands. In some cases, the river bank itself is scooped first for brick making and then intervening sand layers for fine aggregates.

It is now well understood that indiscriminate sand mining leads to serious environmental problems in river basin. Excavation of sand from the neighbouring areas of the river banks cause not only for the 
disfigurement of the land but also for the lowering of water table in that area. The sand mining in the adjoining flood plains has widened the river channel in all these mining sites.

Table 2

Widening of River Course

\begin{tabular}{|l|l|l|l|}
\hline Sl.No & Sand Mining Site & $\begin{array}{l}\text { River width in 1961 } \\
\text { (metres) }\end{array}$ & River width in 2008 (metres) \\
\hline 1 & Arakkunnu & 72.33 & 134.41 \\
\hline 2 & Palakkadavu & 57.64 & 183.42 \\
\hline 3 & Olathani & 56.44 & 125.16 \\
\hline
\end{tabular}

The width of the river in Olathani was $56.44 \mathrm{~m}$ in 1961, which has increased to $125.16 \mathrm{~m}$ in 2008 (Table.2).Sand mining in the Palakkadavu area has widened the river from $57.64 \mathrm{~m}$ in 1961 to 183.42 meters and in Arakkunnu area it is from $72.33 \mathrm{~m}$ in 1961 to 134.41 meters in 2008. Erosion of the river banks and the changes in the river course are severe in the Arakkunnu area. The river course which was curved in the Arakkunu area has been bifurcated and straightened due to the creation of an artificial bund in the right river bank for a length of $112 \mathrm{~m}$. The two bridges (one Road Bridge and one Railway Bridge) in the Arakkunnu area were constructed when the river course was not metamorphosed. However, the present changed course of the river is threatening the very existence of these structures since the river banks are eroding at a fast rate. Unless the river banks are strengthened urgently and the sand excavation in these areas is stopped, the bridges will collapse in near future. Apart from this, it is also noted that the agricultural fields adjacent to the river banks in the area are negatively affected due to the continued river bank erosion. Thirty four coconut trees were uprooted during the recent rainy season in the Arakkunnu area alone owing to this.

Flood plain sand mining has led to the loss of adjacent lands which includes both private and government properties. A loss of more than 50 acres of land has been reported in the Olathani area alone. Apart from a huge loss of land, it also poses threat to ecological and landuse aspects in the area. Extraction of top soil after the removal of natural vegetation transforms the fertile alluvial plains into wasteland, not suitable for agriculture.
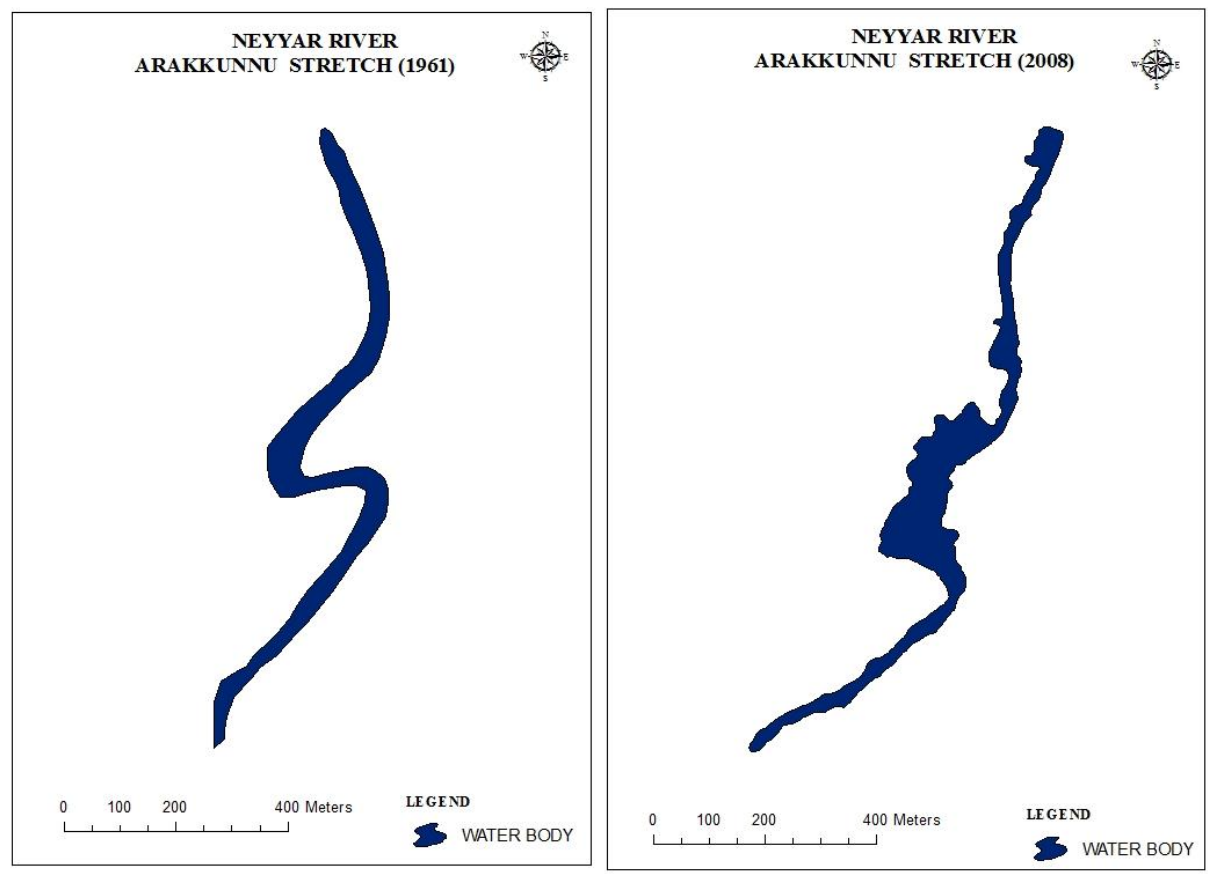

Fig.3 Changed river course in Arakkunnu area 

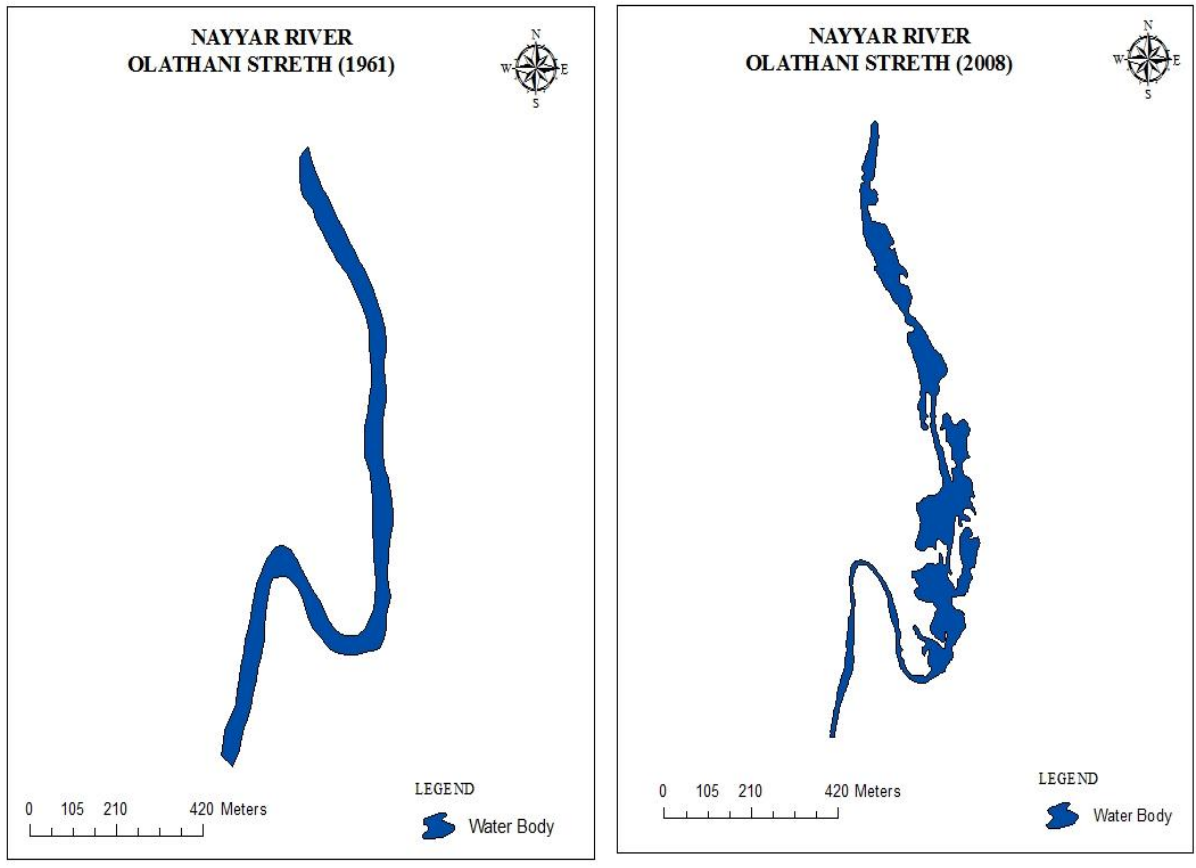

Fig. 4 Changed river course in Olathani area
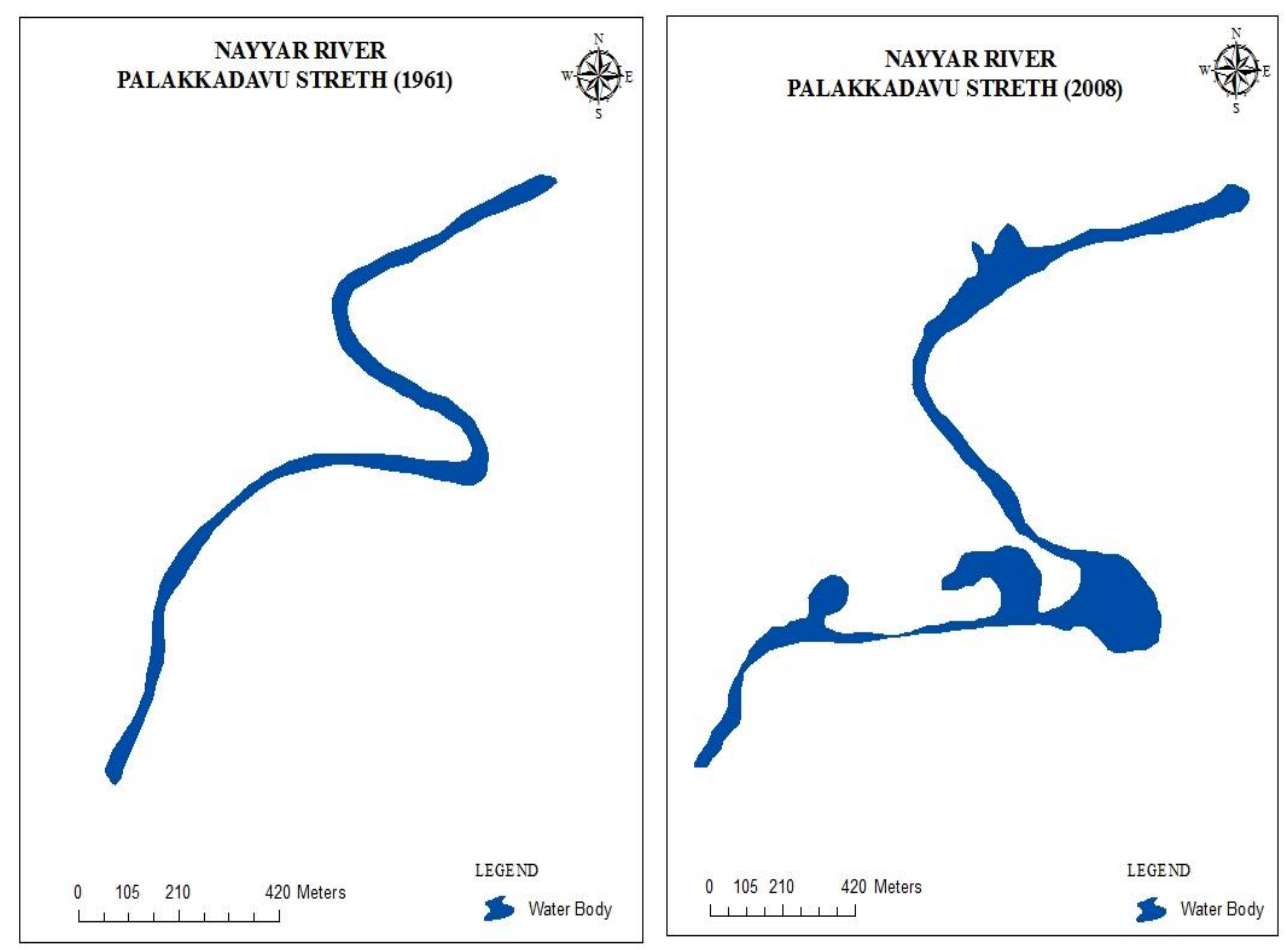

Fig.5 Changed river course in Palakkadavu area 
Sand mining has a direct effect on the quality of water available in the area. The water which is available now is of poor quality and is mainly due to sand mining (CWRDM, 20o9). Assessment of samples collected from these areas has revealed that the water is unsuitable for irrigation. There has been substantial increase of $\mathrm{pH}$ value of water in the area. Well water levels in Olathani and Arakkunnu areas have lowered due to the sand mining. Spreading of the marshy lands is of a serious issue in the sand mining sites of Arakkunnu and Olathani. As revealed during the investigation, stagnation of water in the sand extracted deep pits of the riverbed favours mosquito breeding and causes the spread of diseases like Malaria in the area which is a serious problem in Arakkunnu, Olathani and Palakkadavu.

\section{Social Impact Of Sand Mining In The Neyyar River Basin}

Illegal sand extraction in the riverbed has far reaching impacts on the society and it has created many disturbances in the social wellbeing of the people in the area. There has been an indiscriminate violation of Kerala River Protection Act, 2002 is taking place in all these selected sites for the present study.

1.1 Increase in the instances of conflicts: The present study reveals that there has been an increase in the instances of conflicts in the area. Majority of the people who engage in the illegal sand mining activities are outsiders with criminal backgrounds. They force the people in different ways to sell of their lands for sand extraction and those who oppose them are attacked. Conflict between criminal groups for the monopoly of sand mining is a usual scene in these areas and in many cases it has lead to murders. The common people are helpless in these instances and they are even threatened by the mafias.

Increase in the alcohol consumption: The value of sand in the market is very high and is more than 750000 rupees per load. This has attracted many young people to indulge in the illegal sand mining activities. The money received from these sources is used for many unhealthy practises. There has been a substantial increase in the alcohol consumption reported from these areas. Even the teenagers are attracted to this trend in these areas which will critically affect the social well being of the people in the near future.

1.3 Increase in the number of deaths due to drowning: The deep pits formed as a result of sand mining have caused the death of more than 25 people in the area and the majority of the victims are teenagers.

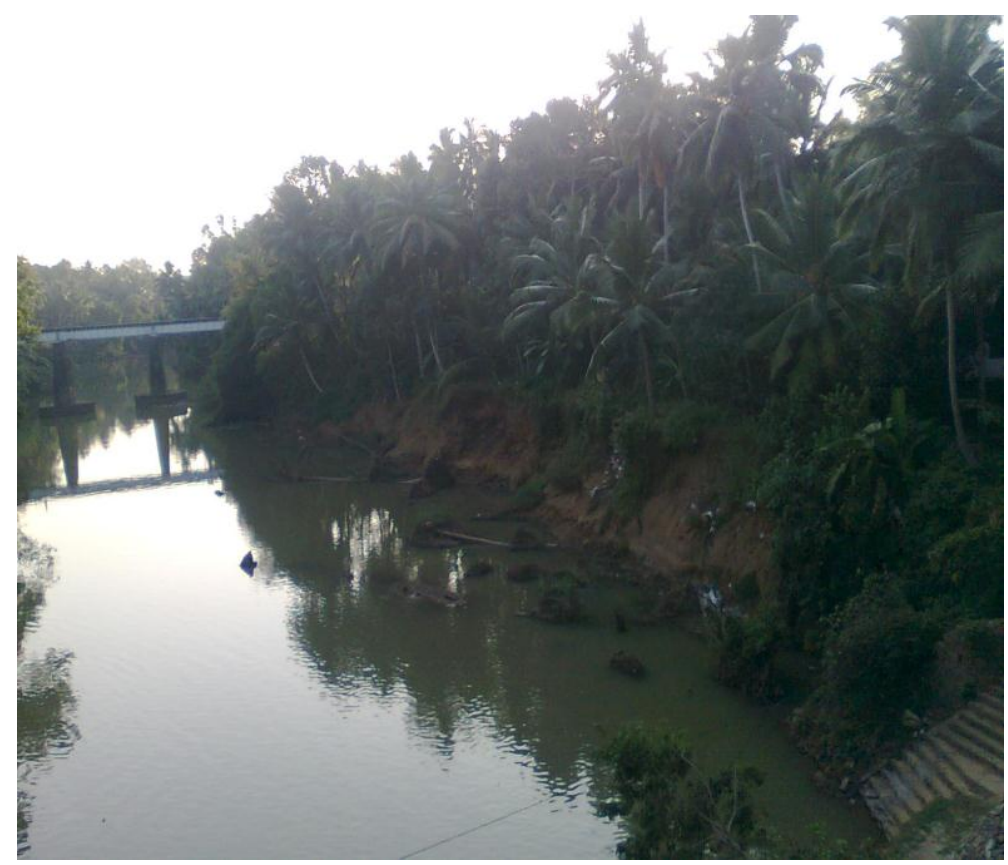

Fig. 6 A railway bridge under threat in Arakkunnu area.

VII.

Conclusion

River sand mining has many negative impacts on the environment as well as in the society. The study conducted in the Neyyar River has established that rivers are dying due to human activities. River bank erosion, valley slumping and river channel widening are severe in this area. Two bridges including a railway bridge and four houses nearby are under the threat of collapse due to river bank erosion in Arakkunnu area. Water quality 
has deteriorated and the water table has lowered in the area. Landuse has changed substantially in all the sand mining sites of the Neyyar river basin. Stagnation of water in the area has lead to many health problems. In the social environment, conflicts, and alcoholism have also increased and is posing a threat to the wellbeing of the people.

\section{Reference}

[1] Naiman R J (1992) Watershed management.Springer,New York

[2] Naiman R J,Bilby RE (1998) River ecology and management in Pacific coastal ecoregion.In:Naiman RJ,Bilby RE(ed) River ecology and management: lessons from the Pacific coastal Ecoregion. Springer,New York,pp 1-22.

[3] Ittekkot V,Lanne RWPM(1991) Fate of riverine particulate organic matter.In:Degens ET,Kempe

[4] Macfarlane M,Mitchell P (2003) Scoping and assessment of the environmental and social impacts of river mining in Jamaica.Warwick Business School, University of Warwick.

[5] KitetuJ,RowanJ(1997)Integrated environmental assessment applied to river sand harvesting in Keniya.In:Patrick CK,Lee N(ed) sustainable development in a developing world-integrated economic appraisal and environmental assessment, Edward Elgar,Cheltenham (U.K.),pp 189-199.

[6] CWRDM (2009) Report on Environmental Monitoring Programme on Water Quality

[7] Padmalal D,Maya K,Sreeba S,Sreeja R (2008) Environmental effects of sand mining : a case from the river catchments of Vembanad lake, Southwest coast of India, Springer . 